\title{
AN INVESTIGATION INTO PUBLIC AND PRIVATE CLIENTS' ATTITUDES, COMMITMENT AND IMPACT ON CONSTRUCTION HEALTH AND SAFETY IN NIGERIA
}

\author{
Nnedinma I Umeokafor \\ Department of Built Environment, Faculty of Architecture, Computing \& Humanities, \\ University of Greenwich \\ Nnedinmaik@hotmail.com
}

\begin{abstract}
Purpose - This paper aims to report the findings of a study that assessed the attitudes, commitment, and impact of public and private sector clients' involvement in construction health and safety $(H \& S)$ in Nigeria.
\end{abstract}

Design/Methodology/Approach - Structured questionnaires were designed based on literature review and a pilot study, and administered to public and private clients in Nigeria's construction industry. Descriptive and inferential statistics were employed to analyse the data.

Findings - The result shows that while clients' attitudes towards H\&S are not encouraging, public clients commitment and attitudes are better than that of private clients. This is emphasised by the significant difference between the categories of clients and: accident investigation; clients auditing contractors $H \& S$ records at the preconstruction stage. The common client H\&S practice includes conducting site visits and inspections and attending H\&S meetings, while engaging in H\&S awareness and H\&S audit during construction are not common. However, when clients are involved in $\mathrm{H} \& \mathrm{~S}$, it has resulted in a reduction in accidents, compensation claims, rework, and improved the relationship between clients and contractors.

Practical implications - The findings form a basis for improving client involvement in H\&S (factoring in the differences in clients) which policymakers, the construction industry and academics will find beneficial.

Originality/Value- The study contributes to understanding the attitudes and commitment of public and private clients in $H \& S$, evidencing the implications of the differences in their needs, characteristics, and behaviours. While the study is the first to investigate the area in Nigeria, it also extends the knowledge of the discourse comparatively in broader terms.

Keywords: attitude, construction industry, commitment, health and safety (H\&S), owner, public sector, private sector.

\section{Introduction}

It can be seen in Alinaitwe (2008) that the description of a client covers who pays for the construction product, the owner, the delegate or representative of the owner. He goes on 
to relate this conceptualisation to encompass the decision-making power of the client in projects, the influence of the client in projects, and the type of client (Alinaitwe 2008). Typically, clients have the responsibility and power to decide who is awarded a contract, thus employing and paying the major project stakeholders (Alinaitwe 2008, Idoro 2010) such as designers, and contractors. Consequently, it can be argued that the client is strategic in the construction supply chain; the pivot on which construction projects thrive, with significant powers and influence throughout the construction process (Emmons 2007; Idoro 2010; Rameezden \& Jaysena 2013; Summer \& Farrell 2003). This includes making health and safety (H\&S) an integral part of the project by taking H\&S measures such as selecting of contractors based on their H\&S records (Emmons 2007), providing funds in excess of the budget cost for H\&S (Huang \& Hinze 2006), ensuring that designers participate in the H\&S process (Lingard et al. 2009), hence improving the challenging state of H\&S reported in studies such as HSE (2014), Ajayi and Thwala (2012). Authors such as Hare et al. (2006) also emphasise the integration of H\&S in preconstruction planning. This would involve, among many, project stakeholders such as the client participation in the planning process where there would be client interaction, inter alia, designer interaction (Hare et al. 2006). However, while some clients are committed to H\&S (Hung 2006; Smallwood 1998, 2004), there are indications that some clients completely hands-off construction activities (Business roundtable 1991; Kometa et al. 2007); their attitudes and commitment to construction H\&S are poor in some countries (Huang \& Hinze 2006; Musonda \& Smallwood 2008; Smallwood 1998) (also see Ogunde et al. 2013).

While various studies examine the role of clients, the attitudes and commitment of clients or their influences in tackling H\&S challenges (Hung 2006; Huang \& Hinze 2006; Kikwasi 2009; Musonda \& Smallwood 2008; Smallwood 1998; Summer \& Farrell 2003) (cf. Ogunde et al. 2013), the concept has mostly been examined holistically, largely neglecting the heterogeneity of clients. Typically, only a few studies, have considered the categories of clients, for example, Hinze (2006), Huang and Hinze (2006), Smallwood (2004). In Lagos state, Nigeria, while Ogunde et al. (2013) have assessed the client compliance level with Construction Design and Management (CDM) Regulations, there is no evidence of a study assessing clients' attitudes, commitment or impact on H\&S holistically or comparatively in Nigeria. Alinaitwe (2008: 74) argues that 'the nature and type of client impacts on the role and contribution a client makes' to construction. Public and private clients differ in various ways such as level of bureaucracy, motives for projects, the responsibility of accountability (New et al. 2002; Rameezden \& Jaysena 2013), attitudes towards H\&S (Huang \& Hinze 2006), needs, funding avenue, to name but a few. These differences impact on these clients differently (Huang \& Hinze 2006; New et al. 2002; Tadelis 2012) determining their attitudes and commitment to H\&S, in turn, impacting on H\&S. Therefore, it can be argued that in effectively improving client attitudes and commitment to $\mathrm{H} \& \mathrm{~S}$, the differences in client objectives, characteristics, inter alia, needs, should be adequately considered.

As a result, the main focus of this research is to assess the attitudes, commitment and impact of the private and public sector clients on construction H\&S in Nigeria. Although Hung (2006) has comparatively examined public and private clients' contribution to 
construction safety in Hong Kong, authors such as Ulubeli et al. (2014) argue for country-specific studies that will address issues specific to countries, providing specific solutions or recommendations to the problems. This is because in many cases, such as in the current study, findings and the recommendations are not transferable because of the differences in contexts of countries, for instance, social and political contexts. Also, there is evidence indicating that the determinants of accidents differ from country to country (Gibb et al. 2014).

\section{Literature review}

Construction $H \& S$

The construction industry is hazardous largely due to the work environment and construction workers (Ajayi \&Thwala 2012), resulting in the high fatality, injury rates, and lost working hours, reported in Ajayi and Thwala (2012), HSE (2014), and Olatunji et al. 2007). For instance, in 2014/15, HSE (2014) reports a loss of 1.7 million working days and 35 fatal injuries in the British construction industry. Although, there is no accurate $H \& S$ statistics in Nigeria, there is evidence of poor $H \& S$ practices such as no health surveillance, no H\&S plan, non-provision of respiratory protective equipment (Olatunji et al. 2007), and a lack of governmental involvement in H\&S (Umeokafor 2015). Clients do not take responsibility for H\&S risks, transferring it to contractors who transfer it to the operatives (Ajayi \& Thwala 2012). Olatunji et al. (2007) observe that clients are not economically committed to H\&S in Nigeria. Furthermore, clients do not attach importance to H\&S when compared to other project parameters (Musonda \& Smallwood 2008; Smallwood 1998), but client commitment to H\&S is observed to improve H\&S (Smallwood 1998, 2004).

Consequently, efforts such as exploiting the strategic position of the client in the construction supply chain by allocating H\&S responsibilities to the client (HSE 2015; Huang \& Hinze 2006; Kikwasi 2009; Lingard et al 2009; Musonda \& Smallwood 2008; Smallwood 1998) is among the ways of improving H\&S. In particular, the CDM Regulations of 2015 place more H\&S responsibility on the client in that, for instance, they should ensure that before the commencement of the project that the contractor prepares a construction phase plan (HSE 2015). In fact, among the overarching aims is effective H\&S planning where the client will be more involved in H\&S. The benefits of effective H\&S planning are demonstrated in Hare and Cameron (2013). The strategic decisions taken at the panning stage of projects determine if the project will be successful thus should be carefully thought through (Hare et al. 2006).

\section{Why should the client be involved in construction $H \& S$ ?}

No direct and indirect incident costs including no litigations which occur in a safe workplace, and the economic incentives remain among the reasons for clients involvement in construction H\&S (Business Roundtable 1991; Emmon 2007). The moral and legal responsibilities for the positive attitudes and commitment to construction $H \& S$ are also significant reasons (Business roundtable 1991). However, the legal responsibilities may only be applicable to some clients who may be bound by construction H\&S laws from outside Nigeria because according to Diugwu et al. (2012) and Umeokafor (2016), the industry is not covered by any local H\&S laws. Commercial 
clients such as property developers stand the risk of losing (prospective) tenants on hearing of multiple fatalities that have occurred on the property site during construction. Although a client is arguably indispensable in the construction supply chain, if contractors view them as prioritising cost, quality, and schedule over H\&S (Musonda \& Smallwood 2008; Smallwood 1998) they may be be viewed as illegitimate in the industry. Clients also stand the risk of unwanted publicity, putting the safety of the public at risk, inter alia, experiencing an increase in the cost of the project (Emmons 2007). Thus, Smallwood (1998) encourages clients to prioritise H\&S. However, issues such as the lack of H\&S awareness, lack of resources both human and financial, may hinder client commitment to H\&S, especially the small clients (Smallwood 1998).

\section{Ways that the client can help improve $H \& S$}

Clients can improve H\&S by ensuring that the practices in Table 1 are carried out. These client practices start from the pre-construction to post-construction stage. Musonda and Smallwood (2008) rightly argue that the client is best placed to take proactive roles, which are more of leading indicators and management approach. Analogously, the model client framework requires that model clients use lagging and leading performance indicators (Lingard et al. 2009). The model client framework has been designed to guide Australian Government agencies on client behaviours to foster positive H\&S culture in construction projects (Lingard et al. 2009). Leading indicators in terms of H\&S seek to prevent and control H\&S. These leading indicators are covered in Table 1; for instance ensuring a mandatory permit to work procedure, providing $H \& S$ training. This is reinforced by the proactive role reported in studies that clients should play during the procurement stage of construction projects. In particular, Business Roundtable (1991) commends awarding contracts to the contractors with good H\&S records, as they are more likely to transfer the safety knowledge and culture to new projects, ensuring a safe workplace than contractors with a poor or average $\mathrm{H} \& \mathrm{~S}$ record.

Table 1: selected previous research on the influence of client on construction H\&S

\begin{tabular}{|c|c|c|c|c|c|c|}
\hline \multirow{2}{*}{$\begin{array}{l}\text { Client practices that contribute to improving } \\
\mathrm{H} \& \mathrm{~S}\end{array}$} & & \multicolumn{5}{|c|}{ Authors } \\
\hline & $\begin{array}{l}\text { Business } \\
\text { roundtable } \\
(1991) \\
\end{array}$ & $\begin{array}{l}\text { Smallwood } \\
(1998)\end{array}$ & $\begin{array}{l}\text { Huang } \\
\& \\
\text { Hinze } \\
\end{array}$ & $\begin{array}{l}\text { Kikwasi } \\
(2008)\end{array}$ & $\begin{array}{l}\text { Musonda \& } \\
\text { Smallwood } \\
(2008)\end{array}$ & $\begin{array}{l}\text { Lingard } \\
\text { et al. } \\
(2009)\end{array}$ \\
\hline & & & $(2006)$ & & & \\
\hline - Make permit to work procedure mandatory & $\mathrm{X}$ & $\mathrm{X}$ & & & & \\
\hline - Provide H\&S manual & $\mathrm{X}$ & $\mathrm{X}$ & & & & \\
\hline $\begin{array}{l}\text { - Specify the appointment of H\&S officer or } \\
\text { representative on site }\end{array}$ & $\mathrm{X}$ & $\mathrm{X}$ & $\mathrm{X}$ & & & \\
\hline - Discuss H\&S in owner-contractor meetings & $\mathrm{X}$ & $\mathrm{X}$ & & & $\mathrm{X}$ & \\
\hline $\begin{array}{l}\text { - Discuss or conduct safety audit of contractors } \\
\text { during construction }\end{array}$ & $\mathrm{X}$ & & & & $\mathrm{X}$ & $\mathrm{X}$ \\
\hline - Make incident reporting mandatory & $\mathrm{X}$ & $\mathrm{X}$ & & & & $\mathrm{X}$ \\
\hline - Make H\&S mandatory in contract documents & $\mathrm{X}$ & & & $\mathrm{X}$ & $X$ & \\
\hline - Conduct accident investigation & $\mathrm{X}$ & $\mathrm{X}$ & $\mathrm{X}$ & & & \\
\hline - Maintain accident statistics & $\mathrm{X}$ & & $\mathrm{X}$ & & & $\mathrm{X}$ \\
\hline - Conduct or monitor safety inspection & $\mathrm{X}$ & & $\mathrm{X}$ & & $\mathrm{X}$ & \\
\hline - Set construction safety goals & $\mathrm{X}$ & & $\mathrm{X}$ & & & \\
\hline $\begin{array}{l}\text { - Consider the H\&S records of contractors } \\
\text { prior to bidding }\end{array}$ & $\mathrm{X}$ & $\mathrm{X}$ & & $\mathrm{X}$ & & $\mathrm{X}$ \\
\hline - Monitor contractor safety & $\mathrm{X}$ & $\mathrm{X}$ & & & & $\mathrm{X}$ \\
\hline
\end{tabular}




\begin{tabular}{|c|c|c|c|c|c|c|}
\hline - Set $\mathrm{H} \& \mathrm{~S}$ guidelines in the contracts & $\mathrm{X}$ & & & $\mathrm{X}$ & $\mathrm{X}$ & $\mathrm{X}$ \\
\hline - Engage in $\mathrm{H} \& \mathrm{~S}$ awareness & $\mathrm{X}$ & $\mathrm{X}$ & $\mathrm{X}$ & & & \\
\hline - Provide or ensure training & & $\mathrm{X}$ & $\mathrm{X}$ & $\mathrm{X}$ & & \\
\hline - Ensure safe work procedure system & & $\mathrm{X}$ & & & & \\
\hline - Prioritise H\&S & & $\mathrm{X}$ & & & $\mathrm{X}$ & $\mathrm{X}$ \\
\hline $\begin{array}{l}\text { - Ensure adequate } \mathrm{H} \& \mathrm{~S} \text { plan, including } \\
\text { method statement and risk assessment }\end{array}$ & & $\mathrm{X}$ & $\mathrm{X}$ & $\mathrm{X}$ & $\mathrm{X}$ & $\mathrm{X}$ \\
\hline - Make H\&S programs elements mandatory & & & & & $\mathrm{X}$ & \\
\hline $\begin{array}{l}\text { Provide contractors with funds beyond } \\
\text { contract sum. }\end{array}$ & & & $\mathrm{X}$ & & & \\
\hline $\begin{array}{l}\text { Take part in safety meetings e.g. tool box } \\
\text { talk }\end{array}$ & & $\mathrm{X}$ & $\mathrm{X}$ & & $\mathrm{X}$ & \\
\hline - Regularly monitor near misses & & & $\mathrm{X}$ & & & \\
\hline $\begin{array}{l}\text { - Ensure that contractors demonstrate the } \\
\text { competence of safety representative }\end{array}$ & & & $\mathrm{X}$ & & & \\
\hline - Ensure that there is H\&S policy & & & & $\mathrm{X}$ & $\mathrm{X}$ & \\
\hline
\end{tabular}

A favourable attitude towards $H \& S$, prioritising $H \& S$ can be through providing funds in excess of the budget cost for H\&S (Haung \& Hinze 2006), adequately addressing H\&S in contract documents (Musonda \& Smallwood 2008), inter alia, making H\&S a major agenda in progress meetings (Kikwasi 2008). Basically, factoring in H\&S at all stages of the project (Lingard et al. 2009).

\section{Differentiation of clients}

Clients are not the same, as they have different understandings, values (Darling and Cunningham (2016), objectives, needs, attitudes, and knowledge, to name but few. This may explain the differentiation of clients by authors. The differentiation of clients can be based on private and public sectors (Idoro 2012; Kometa et al. 2007; Rameezden \& Jaysena 2013), including property developers (Kometa et al. 2007). Public sector clients include various arms of the government namely central, state and local governments, while the private clients include individuals, NGOs, companies whose aim for the project is not for rent. Some clients can also have the aim of making profits and this includes developers. Another classification of clients is based on experience and frequency of engaging in construction projects (Masterman \& Gameson 1994 and Naoum \& Mustapha 1994 in Alinaitwe 2008). This study focuses on private and public sector clients.

Explanations for the differences between public and private sector clients and comparison of their characteristics

The two types of clients in this discourse differ in some areas. Unlike private sector clients, the public sector client is accountable to the taxpayer and the level of bureaucracy in their activities is higher when compared to the private client (Rameezden \& Jaysena 2013). The level of bureaucracy may to some extent hinder public sector client (New et al. 2002) involvement in H\&S. Conversely, being accountable to the taxpayer may drive the public sector clients to be more committed to H\&S. While private sector clients such as developers are inspired by the profit from their investments (Rameezden \& Jaysena 2013), public sector clients are largely not. Thus, economic arguments for H\&S may be impactful on the former than on the latter.

From the finding of Huang and Hinze (2006), they suspect that the contract-awarding 
process of private sector clients may enable them to have a better safety record than the public sector clients in projects. This stems from the premise that pubic sector clients do not consider the safety records of contractors during bidding, awarding the contract on a competitive basis, while the private sector clients may consider safety-related criteria prior to awarding contracts (Huang \& Hinze 2006). Summer and Farrell (2003) suspect that competitive bidding is core to accident causation in the construction industry.

Most of the findings and arguments above may indicate what may be applicable to Nigeria because the government is the major contributor to the construction industry (Dantata 2007; Odediran et al. 2012). The same can be said of bureaucracy in the public sector. The level of corruption in Nigeria may impact more on construction $\mathrm{H} \& \mathrm{~S}$ in public client funded projects, as more parties would have to be 'settled' - bribed. This, in turn, affects the funds allocated to H\&S, if any is allocated. However, tight restrictions on the public sector procurement systems due to regulation as against flexible procurement systems for the private sector results in transparency, eliminating corruption in the public sector (New et al. 2002; Tadelis 2012). Additionally, the rigid regulatory approach in the public sector may be beneficial for instituting H\&S programs just as it can be seen in New et al. (2002) in terms of green criteria.

Furthermore, in developing economies such as Nigeria, public sector clients such as government agencies may ignore $\mathrm{H} \& \mathrm{~S}$ issues with impunity more than private sector clients, as they view themselves above the law and immune to prosecution. Lastly, public sector clients are largely likely to engage in formal construction, while private sector clients with the exception of International NGOs, large cooperate organisations, are likely to engage in informal construction (cf. Ajayi \& Thwala 2012). The small private clients such as individuals mostly patronise small contractors for small projects. These contractors rely on the labour intensive process perhaps because of cost and may not adopt the usual procurement methods (Ajayi \& Thwala 2012). These result in varying procurement routes, nature of risks, nature of agreements, inter alia, financial status, and construction process.

In addition to the constituent of the public and private sectors, in the preceding section, a further explanation for the differences in the public and private clients is the large budget and scale of projects by public clients, which is more than that of private clients (Lu et al. 2016). Indeed, the private sector is mainly involved in real estate development, but the public sector is mainly involved in institutional premises development, for example, government offices, town halls (Australian Bureau of Statistics 2010 in Francis et al. 2013; Lu et al. 2016). This is explained by the responsibility of the public sector of managing the economy, serving the people, non-profit oriented motives as against the private sector that is profit oriented, and less controlled by the government but may have to comply with laws. Furthermore, $\mathrm{Lu}$ et al. (2016) argue that the social and political influence is higher on public clients than private clients. The private sector is likely to be under no or little political influence as the public sector, as they are accountable to the public. Darling and Cunningham (2016) also discuss how the environmental and structural influence impact on the public and private organisations. These explain the differences in the public and private sectors context and environments (cf. Darling \& Cunningham 2016). 
However, the two types of clients have things in common. The strategic position of the client in the construction supply chain, which applies to both the public sector and private sector client, is an example. This is in addition to the powers, responsibilities and the challenges discussed in the introductory section, which also apply to both. Kometa et al. (2007) also report similarities in the communication avenue and the organisational structure of both types of clients, which impacts, on their needs.

\section{Summary of literature discussion}

Based on the discussion so far, it is evident that the disposition of clients in the construction supply chain is pertinent in improving and sustaining H\&S. However, the attitudes and level of client commitment to H\&S are likely to differ between public and private clients, suggesting the likelihood of a difference in their impact on H\&S performance, and little is known of the discourse in Nigeria. Therefore, the need to create awareness and understanding of the attitudes and level of commitments of clients in Nigeria, with emphasis on their categories is underpinned and underscored. Furthermore, it is evident in the preceding section that the characteristics of the two categories of clients and the contexts they operate in present them with different strengths, weaknesses, opportunities and threats (SWOT) to their involvement in H\&S. Hence, without empirical evidence, it is naïve to conclude SWOT client involvement in H\&S impact on one category of client more than the other.

\section{Research methods}

Sampling and data collection

A preliminary survey of ongoing construction projects was conducted in (Ekiti, Enugu, Kogi and Rivers states) four of the six geopolitical zones in Nigeria, North Central, South South, South East and South East. To avoid repetition of respondent projects, one major project was selected for each client from the list of clients during the survey. The survey showed 249 public and private sector projects, which was used as the population. The rational for conducting the preliminary survey is the non-availability of a comprehensive list of clients in the population. Preliminary surveys of the aforesaid nature due to lack of a comprehensive list is consistent with studies such as Idoro (2012). More importantly, the respondents are from different environments, where the level of H\&S knowledge and awareness differ; this ensured that the sample is not skewed to a particular level of H\&S awareness and knowledge. In particular, clients and consultants from Rivers state may have a higher level of knowledge in terms of H\&S and may even be more involved in $\mathrm{H} \& \mathrm{~S}$ because of the influence of the oil and gas industry in the geopolitical zone as Umeokafor (2016) suggests. Furthermore, Federal government as a client may take part in H\&S and have a higher level of knowledge of H\&S than local government as a client. Conversely, addressing these clients holistically presents a combination of all the three levels of government, federal, state and local showing the attitudes of pubic clients holistically.

After reviewing literature that examined the role of clients or client contribution to H\&S and studies that examined client involvement in construction, the questionnaire was developed. The literature includes Musonda and Smallwood (2008), Smallwood (1998) and Huang and Hinze (2006). In adequately addressing H\&S issues in developing 
countries, their contexts need to be factored in (International Labour Organisations (ILO) 2009; Kheni et al., 2010; Umeokafor, 2015). Hence, the themes or survey questions in the previous studies were improved or contextualised to the Nigerian construction industry. The experiences of the investigator were also factored in while polishing the data collection instrument. It was then piloted to 27 clients or their representatives such as architects. Eight academics also participated in the pilot survey, offering both academic and practitioner input to the study. In addition to academic roles and responsibilities, seven of the academics also have practitioner roles. Additional short pilot interviews were also conducted on two client representatives. On receipt of the pilot data, the pilot questionnaires were revised and administered to clients and their representatives. The questionnaires were electronically and self-administered. While reminder text messages and emails were sent to respondents that the investigators had their contact details, reminding them of the questionnaires, there were also follow-up visits for the rest. Sampling clients and/or their representatives who are consultants in addressing issues relating to the context of this study is consistent with studies such as Alinaitwe (2008), Kometa et al. (1995). According to Alinaitwe (2008), consultants who represent clients are more knowledgeable than the client because they are deeply involved in the projects. Thus, it is logical to seek their views or experiences in addressing issues that relate to clients. Seventy-six projects in each of the public and private projects, a total of 152 were randomly sampled from the population frame. Of the distributed questionnaires, 103 useable ones were returned, a 67.8 per cent response rate. According to Fellows and Liu (1997), in questionnaire survey, this is acceptable and above the norm of 20-30 per cent response rate. Furthermore, there were questions on the impact of client involvement in H\&S, which will be better addressed by consultants, so only consultants were asked the questions. Typically, they were asked to note the impact of client involvement and nature of improvement as per $\mathrm{H} \& \mathrm{~S}$ that they have experienced in the organisations based on a recently completed project in the last two years or the ongoing project (Huang \& Hinze 2006).

\section{Data collection instrument}

The questionnaires were in two sections with section one covering the description the study sample. Section two appraised the following: client or client representative activities in terms of $\mathrm{H} \& \mathrm{~S}$; client mandatory $\mathrm{H} \& \mathrm{~S}$ practices or requirement for contractors; the attitudes of clients towards $\mathrm{H} \& \mathrm{~S}$ with the degree of attention they give to improving H\&S, whether there were improvement and the extent of improvement that were witnessed in the project. Some questions were in nominal scale 'Yes' and 'No' options and in some cases, 'unsure' option. Other questions were also made up of a likert scale of various types, for instance, 5 for very important to 1 for unimportant, 5 for fully addressed to 1 for not addressed. In testing the reliability of the data collection instrument, Cronbach Alpha test was conducted. For the Likert scale, .911 was the result, but the nominal scale was not tested because it is internally consistent.

\section{Data analysis}

Using Statistical Package for Social Science (SPSS), the data collected were analysed with mean, percentage, chi-square, and Mann-Whitney test. The non-parametric test was adopted because the data did not meet the assumptions of a parametric test. 


\section{Results and discussion}

\section{Description of the study sample}

The 103 useable questionnaires comprise of 42 respondents from private client organisations and 61 from public client organisations. Of the 103 useable questionnaires, 35 were completed by clients and 68 by consultants. While these consultants are not limited to architects, builders, civil engineers, they were project leaders, deeply involved in the projects.

The attitudes and commitment of clients to $H \& S$.

While providing funds for $\mathrm{H} \& \mathrm{~S}$ is commendable, doing so in excess of the contract sum for H\&S demonstrates clients' strong commitment and attitude towards H\&S, so it was assessed. Table 2 shows that while 72.8 per cent views that their clients do not provide funds in excess of the budget cost for H\&S, 27.2 per cent views otherwise. While this finding is in contrast with Haung and Hinze (2006) where over half of the respondents, 35 out of 59, note that clients provide funds in excess of the budget cost for H\&S, it tends to be consistent with the finding of Olatunji et al (2007) that clients are not economically committed to H\&S. The aforesaid contrast may be explained by the contexts of the study, Haung and Hinze (2006). Indeed, the clients in Haung and Hinze (2006) may have a better $H \& S$ understanding of the benefits of $H \& S$, there are effective H\&S laws and regulatory system in the USA and a better emerged H\&S system than in Nigeria. The forgoing finding also suggests why contractors may not be committed to $\mathrm{H} \& \mathrm{~S}$. According to authors such as Umeokafor (2016), lack of funds hinders the involvement of small and medium contractors in $H \& S$ as against large firms who are financially capable in terms of $H \& S$. Therefore, if contractors lack funds for $H \& S, H \& S$ may become secondary or low on their priority list.

Table 2: Provision of funds in excess of the budget cost for H\&S

\begin{tabular}{lllccl}
\hline Respondents & \multicolumn{5}{c}{ Responses } \\
\cline { 2 - 6 } & Yes & No & Total \\
\cline { 2 - 6 } & Freq. & $\%$ & Freq. & $\%$ & Freq. \\
\hline Public clients & 21 & 34.4 & 40 & 65.6 & 61 \\
Private clients & 7 & 16.7 & 35 & 83.3 & 42 \\
\hline Overall & 28 & 27.2 & 75 & 72.8 & 103 \\
\hline
\end{tabular}

Table 2 also shows that 65.6 per cent of the public clients and 83.3 per cent of the private clients do not provide funds in excess of the budget cost for H\&S. It is, therefore, logical to conclude that the attitudes of public clients towards H\&S in this question are better than that of their counterparts. This is consistent with the finding that more public clients provide funds in excess of the budget cost for H\&S which may be explained by their accountability to the taxpayer (Rameezden \& Jaysena 2013) and the possibility that public clients mostly engage large contractors for large-scale projects. This may also be explained by the fact that the H\&S legislation and standards that these large contractors adhere to which may be adopted from developed countries or their parent companies overseas (Umeokafor 2016), may result in the public clients providing funds for H\&S which can be over the contract sum. Also, it should be recalled that literature review reveals that public clients have a larger budget and scope of projects than private clients, 
another possible explanation. Conversely, it is possible to ague that if this is the case, then private clients should exploit the cost-benefits of engaging in $H \& S$ in their projects. Of course, this is if the private clients have a good understanding of the benefits of H\&S of which may not be the case as many studies such as Umeokafor (2017) and Diugwu et al. (2012) indicate or demonstrate the poor level of H\&S awareness in the Nigerian construction industry. Nonetheless, the implication of the results in Table 2 is that the contractors in the public sector projects will have more funds for H\&S than their counterparts in the private sector projects hence a better H\&S records.

To see if there is a statistical association between the categories of clients (i.e. public and private clients) and providing funds in excess of the contract sum for H\&S, a Pearson Chi-square test was conducted. At a significance level of $\leq .05$, the Chi-square test shows a Chi-square statistics of 3.963 and a p-value of .047. This indicates that there is a statistical association between the categories of clients and providing funds in excess of the contract sum for $\mathrm{H} \& \mathrm{~S}$.

The respondents were then asked the level of importance that clients attach to H\&S when compared to other Project Performance Indicators (PPIs). Of the PPIs in Table 3, H\&S is viewed as the least important with a mean score (MS) of 3.37. Comparatively, both categories of clients are found to attach little importance to H\&S. This is consistent with Aje (2012), Musonda and Smallwood (2008), Smallwood (1998). Typically, Aje (2012) found that at prequalification of contractors, clients, contractors and consultants attach less importance to $\mathrm{H} \& \mathrm{~S}$ records when compared to other prequalification criteria such as technical, financial, and managerial capabilities. Similarly, Musonda and Smallwood (2008) found that of the PPIs, cost within budget, quality, contract period, avoiding litigation, and $\mathrm{H} \& \mathrm{~S}, \mathrm{H} \& \mathrm{~S}$ is viewed as the least important. Conversely, Kometa et al. (1995) and Smallwood (2004) found that clients attach a higher level of importance to safety compared to other PPI such as quality, time, cost, and flexible uses. A possible explanation for this difference is that Smallwood (2004) has examined Shell construction contractors. Shell construction contractors work for the oil and gas industry where the level of risk is also high; hence, they take H\&S seriously. For Kometa et al. (1995), the data was collected from a developed country with a better H\&S system than that of Nigeria. Lingard et al. (2009) while presenting the earlier noted 'model client framework' show how the framework demonstrates the imperativeness of integrating safety objectives as a project objective just like time, cost and quality. The model goes on to stress that other project parameters should not compromise H\&S. Hare and Cameron (2012) argue that as much as H\&S should be integrated as a project objective, an effective management system should ensure that all project parameters in Table 3 are not compromised at the expense of each other. While this may be challenging, it ensures that there is effective management and a successful project.

Table 3: the extent of importance attached to cost, quality, productivity and H\&S

\begin{tabular}{|c|c|c|c|c|c|c|}
\hline \multirow{2}{*}{$\begin{array}{l}\text { Project } \\
\text { Performance } \\
\text { indicators (PPI) }\end{array}$} & \multicolumn{2}{|c|}{$\begin{array}{l}\text { Private } \\
\text { clients }\end{array}$} & \multicolumn{2}{|l|}{$\begin{array}{l}\text { Public } \\
\text { clients }\end{array}$} & \multicolumn{2}{|c|}{ Overall } \\
\hline & Mean & Rank & Mean & Rank & Mean & Rank \\
\hline Cost & 4.45 & 1 & 4.49 & 1 & 4.48 & 1 \\
\hline Productivity & 4.38 & 2 & 4.20 & 3 & 4.27 & 2 \\
\hline
\end{tabular}




\begin{tabular}{lllllll}
\hline Quality & 4.14 & 3 & 4.28 & 2 & 4.22 & 3 \\
H\&S & 3.24 & 4 & 3.46 & 4 & 3.37 & 4 \\
\hline
\end{tabular}

Nonetheless, Table 3 contributes to explaining the poor H\&S in Nigeria's construction industry, emphasising that the level of client awareness as per H\&S is poor. This is because the direct and indirect costs of H\&S incidents increase project cost and duration, reduce productivity and even impact on the image of the client. Therefore, attaching little importance to $H \& S$ is detrimental to the client. Furthermore, as $H \& S$ is viewed as less important (Table 3), it is axiomatic that it will receive less attention, including financial attention as found in Table 2. The two preceding sentences show the significant implications of attaching less importance to $\mathrm{H} \& \mathrm{~S}$ as against other PPIs.

Table 4: the extent of importance attached to cost, quality, productivity and H\&S: results of the Mann-Whitney test

\begin{tabular}{lllll}
\hline $\begin{array}{l}\text { Project performance } \\
\text { indicators (PPI) }\end{array}$ & $\begin{array}{l}\text { Mann-Whitney } \\
(\mathrm{U})\end{array}$ & $\begin{array}{l}\text { Asymp.Sig } \\
\text { 2-tailed }\end{array}$ & Z score & Decision \\
\hline Cost & 1267.0 & .911 & -.111 & Accept \\
Quality & 1153.5 & .350 & -.935 & Accept \\
H\&S & 1167.5 & .433 & -.783 & Accept \\
Productivity & 1128.0 & .258 & -1.131 & Accept \\
\hline
\end{tabular}

To further investigate the result in Table 3, assessing if there is a difference in the views of the two categories of clients on the extent of importance attached to cost, quality, productivity and H\&S, a Mann-Whitney test was conducted and presented in Table 4. The significance level of $\mathrm{p} \leq .05$ was adopted. Table 4 shows that there is no significant difference in the responses of the respondents in private and public client organisations in the level of importance attached to PPIs. The implications of this is that there is consensus on the extent of importance attached to cost, quality, productivity and H\&S and this can be by chance, thus not reliable.

H\&S as a major agenda in progress meetings was assessed. According to Table 5, the descriptive analysis shows that in more of public projects, 68.9 per cent, H\&S is a major agenda in progress meetings, but only a major agenda in 38.1 per cent of private sector projects. In total, it can be seen that $H \& S$ is a major agenda in progress meetings in only 56.3 per cent of the projects assessed. While this agrees a little with Kikwasi (2008) where a majority of the clients ensure that $H \& S$ is a major agenda in site meetings, it is in contrast with the finding of Musonda and Smallwood (2008) who found that only 28 per cent of clients make H\&S a major agenda in progress meetings. This contrast may be explained by the fact that Musonda and Smallwood (2008) address client commitment and attitudes towards H\&S from a holistic perspective. The Chi-square statistics shows that at a significance level, $\leq .05$, there is a statistical association between the categories of clients and H\&S being a major agenda in progress meetings. This is where the Pearson Chi-square statistics is 9.565 and p-value, .002 .

Table 5: assessment of H\&S being a major agenda in progress meetings

\begin{tabular}{|c|c|c|c|c|}
\hline \multirow[t]{3}{*}{ Respondents } & \multicolumn{4}{|c|}{ Responses } \\
\hline & Yes & No & & Total \\
\hline & Freq. $\%$ & Freq. & $\%$ & Freq. \\
\hline
\end{tabular}




\begin{tabular}{llllll}
\hline Public clients & 42 & 68.9 & 19 & 31.1 & 61 \\
Private clients & 16 & 38.1 & 26 & 61.9 & 42 \\
\hline Overall & 58 & 56.3 & 45 & 43.7 & 103 \\
\hline
\end{tabular}

The next question assessed the extent that $\mathrm{H} \& \mathrm{~S}$ is addressed in contract documents (Table 6). The descriptive statistics shows that while only 43.6 per cent of clients overall address and fully address H\&S in contract documents, more public clients (59 per cent) address and fully address H\&S in the contract documents than private clients $(21.4$ per cent) (Table 1). One of the explanations to the low number of private clients that address H\&S in contract documents may be that a smaller number of private clients use standard contract documents unlike public clients. Further explanations may include that there is not legal backing for $H \& S$ to be in contract documents. Even if they are there, the enforcement may be farfetched. It should be recalled that the literature review shows that local construction H\&S laws do not cover the Nigerian construction sites and activities.

Table 6: the extent that H\&S is addressed in contract documents

\begin{tabular}{|c|c|c|c|c|c|c|}
\hline \multirow{2}{*}{$\begin{array}{l}\text { Category of } \\
\text { client }\end{array}$} & \multicolumn{4}{|c|}{ Extent that H\&S is addressed in contract documents } & \multirow[b]{2}{*}{$\begin{array}{l}\text { Fully } \\
\text { addressed } \\
(\%) \\
\end{array}$} & \multirow[b]{2}{*}{ Overall MS } \\
\hline & $\begin{array}{l}\text { Not } \\
\text { addressed } \\
(\%)\end{array}$ & $\begin{array}{l}\text { Slightly } \\
\text { addressed } \\
(\%)\end{array}$ & $\begin{array}{l}\text { Fairly } \\
\text { addressed } \\
(\%)\end{array}$ & $\begin{array}{l}\text { Addressed } \\
(\%)\end{array}$ & & \\
\hline Public & $4 \quad(6.6)$ & $13 \quad(21.3)$ & $8 \quad(13.1)$ & $16(26.2)$ & $20(32.8)$ & 3.57 \\
\hline Private & $12(28.6)$ & $7 \quad(16.7)$ & $14(33.3)$ & $3(7.1)$ & $6 \quad(14.3)$ & 2.62 \\
\hline Overall & $16(15.5)$ & $20(19.4)$ & $22(21.4)$ & $19(18.4)$ & $26(25.2)$ & 3.18 \\
\hline
\end{tabular}

The Mann-Whitney $U$ test shows that there is a significant difference in the responses of the public and private clients where the Mann-Whitney $U=796.5, p=.001$ (at $p$-value, $\leq$ $.05), \mathrm{Z}$ score $=-3.345$. Unlike in Table 4 where all the hypotheses were accepted so the effect sizes ' $r$ ' were not calculated, the ' $r$ ' in this case was calculated. Sullivan and Feinn (2012) note that the major finding of a quantitative study is the effect size, as it offers insight into the data, therefore, should be reported. Typically, while the p- value shows if there is a difference or not, the effect size shows the extent of the difference between the groups (Sullivan \& Feinn 2012). To calculate the effect size $(r)$, the formula, $r=z$ /square of $\mathrm{N}$ is adopted. This is where $\mathrm{Z}$ is $\mathrm{Z}$ score; and $\mathrm{N}$, the number of cases - 103. The $r$ is small if $=0.20$, medium if $=0.50$ and large if $=0.80$ (Cohen 1988). The $r$ was calculated and showed a value of -0.329 , a medium effect. The implication of this it is unlikely that there is no agreement on the extent that H\&S is addressed in contract documents. This is unlikely to be due to chance.

When clients insist that contractors engage in some H\&S practices, H\&S is improved. Table 7 presents some of these practices or requirements, comparing private and pubic clients. It shows that public clients have a better attitude towards H\&S than private clients. This is because on the entire variables in Table 7, public clients scored higher than private clients. This offers some level of optimism in that public clients do not stop at ensuring that H\&S is addressed or fully addressed in contract documents but they go further to insist that contractors engage in H\&S practices. While the finding in Table 7 is consistent with the findings of Hung (2006) in that public client involvement in safety is greater than that of private sector client, it contrasts the findings of Huang and Hinze 
(2006) that the attitude of public sector clients toward safety is inadequate compared to private sector clients. A possible explanation for the difference may be the location of the study, as earlier noted.

Table 7: client mandatory H\&S practices or requirements for contractors

\begin{tabular}{|c|c|c|c|c|c|c|c|c|c|c|c|c|c|c|}
\hline \multirow{2}{*}{$\begin{array}{l}\text { Client H\&S practices or } \\
\text { requirements for } \\
\text { contractors }\end{array}$} & \multicolumn{6}{|c|}{ Yes } & \multicolumn{6}{|c|}{ No } & \multirow{2}{*}{$\begin{array}{l}\text { Chi- } \\
\text { square }\end{array}$} & \multirow{2}{*}{$\begin{array}{l}\text { Asym } \\
\text { p. Sig }\end{array}$} \\
\hline & \multicolumn{2}{|c|}{$\begin{array}{l}\text { Public } \\
\text { Client }\end{array}$} & \multicolumn{2}{|c|}{$\begin{array}{l}\text { Private } \\
\text { Client }\end{array}$} & \multicolumn{2}{|c|}{ Overall } & \multicolumn{2}{|c|}{$\begin{array}{l}\text { Public } \\
\text { client }\end{array}$} & \multicolumn{2}{|c|}{$\begin{array}{l}\text { Private } \\
\text { Client }\end{array}$} & \multicolumn{2}{|c|}{ Overall } & & \\
\hline H\&S policy & 41 & 67.2 & 8 & 19.0 & 49 & 47.6 & 20 & 32.8 & 34 & 81 & 54 & 52.4 & 23.137 & .001 \\
\hline Safe work procedures & 50 & 82.0 & 20 & 47.6 & 70 & 68 & 11 & 18 & 22 & 52.4 & 33 & 32 & 13.478 & .001 \\
\hline $\begin{array}{l}\text { Welfare facilities such as } \\
\text { toilets }\end{array}$ & 39 & 63.9 & 13 & 31 & 52 & 50.5 & 22 & 36.1 & 29 & 69 & 51 & 49.5 & 10.824 & .001 \\
\hline $\mathrm{H} \& \mathrm{~S}$ representative & 30 & 49.2 & 8 & 19 & 38 & 36.9 & 31 & 50.8 & 34 & 81 & 65 & 63.1 & 9.701 & .002 \\
\hline Training of contractor & 29 & 47.5 & 9 & 21.4 & 38 & 36.9 & 32 & 52.5 & 33 & 78.6 & 65 & 63.1 & 7.285 & .007 \\
\hline Obtain a permit to work & 35 & 57.4 & 17 & 40.5 & 52 & 50.5 & 26 & 42.6 & 25 & 59.5 & 51 & 49.5 & 2.842 & $.092 *$ \\
\hline Method statement & 31 & 50.8 & 12 & 28.6 & 43 & 41.7 & 30 & 49.2 & 30 & 71.4 & 60 & 58.3 & 5.063 & .024 \\
\hline $\begin{array}{l}\text { Ensure the competence of } \\
\text { subcontractors. }\end{array}$ & 46 & 75.4 & 21 & 50 & 67 & 65 & 15 & 24.6 & 21 & 50 & 36 & 35 & 7.064 & .008 \\
\hline $\begin{array}{l}\text { Mandatory accident } \\
\text { reporting }\end{array}$ & 31 & 50.8 & 16 & 38.1 & 47 & 45.6 & 30 & 49.2 & 26 & 61.9 & 56 & 54.4 & 1.623 & $.203^{*}$ \\
\hline
\end{tabular}

When a Pearson Chi-square test was performed, at a significance level of $\leq .05$, it showed that there was no statistical association between the two categories of clients and the $\mathrm{H} \& \mathrm{~S}$ practice, requiring that contractors obtain a permit to work. There was also no statistical association between the two categories of clients and the requirement, making accident-reporting mandatory.

Meanwhile, a safe work procedure, a proactive practice, is the most mandatory of contractors by clients - 68 per cent. Furthermore, a comparative assessment shows that more public clients, 82 per cent, requires contractors to have a safe work procedure than private clients. Overall, the next mandatory requirement is that contractors ensure that subcontractors are competent, another proactive practice. This is revealing as authors demonstrate that subcontracting both in and out of the construction industry contributes to the challenging state of H\&S (Manu et al. 2009). However, the H\&S record of the Nigerian construction industry tends not to reflect the contribution of clients in that regard. This may be explained by a lot of factors such as the quality or criteria for assessing the subcontractors in the Nigerian construction industry. This is an area that an ongoing study is investigating.

Conversely, while overall, most clients (64.1 per cent) do not require contractors to set H\&S goals, a higher percentage of private clients (78.6) tends to overlook requiring contractors to set H\&S goals more than public sector clients. This is followed by clients ensuring that there are $H \& S$ representatives in contracting firms, and requiring that contractors train their employees, both at 63.1 per cent respectively. Other findings in 
Table 7 that are reported in studies are not limited to: H\&S policy, safe work procedure, maintaining accident records (Haung \& Hinze 2006; Smallwood 1998; Musonda \& Smallwood 2008).

While clients require contractors to engage in certain H\&S practices, there are some that clients or their representatives should do at various stages of the projects (Tables 1 and 8). Most of these practices make a model client (Lingard et al. 2009) which is noted elsewhere in this paper. It can be seen in Table 8, that overall, clients mostly attend H\&S meetings, and in terms of categories, the same is applicable.

Table 8: client H\&S practices

\begin{tabular}{|c|c|c|c|c|c|c|c|c|c|c|}
\hline \multirow{2}{*}{$\begin{array}{l}\text { Client } \\
\text { H\&S } \\
\text { practices }\end{array}$} & \multicolumn{2}{|c|}{$\begin{array}{l}\text { Public } \\
\text { clients }\end{array}$} & \multicolumn{2}{|c|}{$\begin{array}{l}\text { Private } \\
\text { Clients }\end{array}$} & \multicolumn{2}{|c|}{ Overall } & \multirow{2}{*}{$\begin{array}{l}\text { Mann-- } \\
\text { Whitney } \\
\text { (U) }\end{array}$} & \multirow{2}{*}{$\begin{array}{l}\text { Asymp. } \\
\text { Sig } \\
\text { 2-tailed }\end{array}$} & \multirow[t]{2}{*}{$Z$ score } & \multirow{2}{*}{$\begin{array}{l}\text { Effect } \\
\text { size (r) }\end{array}$} \\
\hline & MS & $\mathrm{R}$ & MS & $\mathrm{R}$ & MS & $\mathrm{R}$ & & & & \\
\hline $\begin{array}{l}\text { Attend site } \\
\text { meetings }\end{array}$ & 4.00 & 1 & 3.33 & 1 & 3.73 & 1 & 857.5 & .003 & -2.993 & \\
\hline Site visits & 3.74 & 2 & 3.29 & 2 & 3.56 & 2 & 964.5 & .025 & -2.245 & \\
\hline $\begin{array}{l}\text { Site (H\&S) } \\
\text { Inspection }\end{array}$ & 3.46 & 3 & 2.86 & 3 & 3.21 & 3 & 908 & .010 & -2.591 & \\
\hline $\begin{array}{l}\text { Monitor } \\
\text { incidents on } \\
\text { site such as } \\
\text { accidents, }\end{array}$ & 3.39 & 4 & 2.67 & 7 & 3.10 & 4 & 844.5 & .003 & -3.014 & \\
\hline $\begin{array}{l}\text { Monitor } \\
\text { contractor } \\
\text { safety }\end{array}$ & 3.34 & 5 & 2.71 & 6 & 3.09 & 5 & 914.5 & .011 & -2.543 & \\
\hline $\begin{array}{l}\text { Warn or correct } \\
\text { the contractors } \\
\text { on unsafe } \\
\text { practices based } \\
\text { on moral } \\
\text { reasons }\end{array}$ & 3.25 & 6 & 2.67 & 7 & 3.01 & 6 & 970 & .031 & -2.157 & \\
\hline $\begin{array}{l}\text { Audit } \\
\text { Contractors } \\
\text { H\&S records at } \\
\text { preconstruction }\end{array}$ & 3.16 & 7 & 2.76 & 4 & 3.00 & 7 & 1051 & $.110^{*}$ & -1.598 & -0.16 \\
\hline $\begin{array}{l}\text { Accident } \\
\text { investigation }\end{array}$ & 3.03 & 8 & 2.74 & 5 & 2.91 & 8 & 1114.5 & $.246^{*}$ & -1.161 & -0.11 \\
\hline $\begin{array}{l}\text { Provide } \\
\text { H\&S } \\
\text { guidelines }\end{array}$ & 3.25 & 6 & 2.43 & 8 & 2.91 & 8 & 825 & .002 & -3.146 & \\
\hline $\begin{array}{l}\text { Discuss H\&S } \\
\text { in owner- } \\
\text { contractor } \\
\text { meetings }\end{array}$ & 3.25 & 6 & 2.38 & 9 & 2.89 & 9 & 722 & .001 & -3.980 & \\
\hline $\begin{array}{l}\text { Engage in } \\
\text { H\&S } \\
\text { awareness }\end{array}$ & 3.00 & 9 & 2.36 & 10 & 2.74 & 10 & 908 & .009 & -2.599 & \\
\hline $\begin{array}{l}\text { H\&S audit } \\
\text { during } \\
\text { construction }\end{array}$ & 2.92 & 10 & 2.43 & 8 & 2.72 & 11 & 988.5 & .043 & -2.025 & \\
\hline
\end{tabular}

This is in agreement with the findings of Haung and Hinze (2006) where 46 of the 56 respondents note that clients attend safety meetings and toolbox talks, and the findings of Smallwood (1998) where it is also very common. Typically, public clients were found to mostly engage in all, but three of the H\&S practices (H\&S audit during construction, accident investigation, audit of construction H\&S records) than the private client (Table 8). Furthermore, according to Table 8, the highest-ranking factor is followed by site 
visits, which rank second and site $H \& S$ inspection which ranks third. According to Smallwood (1998), client conducting site inspections rank second with an MS of 1.65 while site visits rank fourth with an MS of 1.62. In terms of the categories, public and private, the aforesaid factors also rank second and third respectively in each category. In contrast, Table 8 shows that overall, clients do not conduct H\&S audit, as it ranks eleventh with an MS of 2.72 and also ranks low, tenth and eighth for both public and private clients respectively. This is consistent with the finding of Musonda and Smallwood (2008) who found that 56 per cent of clients never conduct H\&S audit and inspection, 28 per cent rarely conduct it and only 8 per cent conducts it sometimes and often respectively. Clients engaging in H\&S awareness also rank low overall, tenth, with an MS of 2.74 and also ranks low between the public and private clients (Table 8). As the pivot of the construction supply chain, if the client drives H\&S awareness, the low level or questionable H\&S awareness reported in Nigeria's construction industry in many studies such as Diugwu et al. (2012) will be improved.

Meanwhile, that the factors that rank the first three are neither preconstruction-related which is proactive nor H\&S appraisal-related raise concern. This is because the audit of contractors $H \& S$ records at preconstruction helps clients make informed decisions, making contractors understand the implications of poor H\&S records in procurement. Auditing contractors $H \& S$ records at the preconstruction stage does not only show how the contractors have performed in terms of H\&S but can also show the skills, knowledge and experience of contractors. Fifty-nine per cent of the accidents caused in USA and 42 per cent in the UK are as a result of workers knowledge and skills (Gibb et al. 2014). The new CDM regulations of 2015 (HSE 2015) also emphasise and define competence to cover skills, knowledge and experience. As a result, contractors may engage in training their workers to ensure they have better chances of securing more contracts. Based on the experiences of the author and on-going research findings, this is one of the factors that make construction contractors in Nigeria adopt and implement H\&S laws despite that the industry is not covered by any local H\&S law as Diugwu et al. (2012) and Umeokafor (2016) note. Nonetheless, considering the complex H\&S regulatory environment of the Nigerian construction industry (Umeokafor 2016) the client practices which foster H\&S offer optimism in terms of H\&S.

Meanwhile, public clients failing to audit the H\&S records of contractors (Table 8) is consistent with Huang and Hinze (2006), as earlier stated. Analogously, accident investigation ranks higher for private clients, fifth, but eighth for public clients. Discussing H\&S in contractor-client meetings which ranks ninth overall with an MS of 2.89 in Table 8 tends to explain or expand Table 5. However, that it ranks low in Table 8 indicates that although it may be a major agenda in H\&S progress meetings at 56.3 per cent overall according to Table 5, among other H\&S practices, it ranks low.

To see if there is a difference in the responses of the respondents from public and private sector projects, a Mann-Whitney test was conducted. It showed that there are significant differences in only two $H \& S$ practices: audit contractors $H \& S$ records at the preconstruction stage and accident investigation. As can be seen in Table 8, the effect sizes of these factors are small, according to Cohen (1998). The implication of this it is 
unlikely that there is no agreement on the H\&S practices: audit contractors H\&S records at the preconstruction stage and accident investigation. This is unlikely to be due to chance.

The impact of client involvement in H\&S on the H\&S performance of organisations. Based on recently completed projects within the past two years or the ongoing project, the consultants were asked to note the impact of client involvement in H\&S on the H\&S performances of their organisations. They were also asked to state the type of client on the project. Of the 68 consultants that answered this question, majority of the respondents, just a little above three quarter, opine that client involvement in H\&S has improved H\&S in their organisations (Table 9); this is consistent with the findings of Smallwood (1998). Indeed, Table 9 shows that a majority of public clients, well above three-quarter, had a positive influence as against a little over half of the private clients that had a positive influence on the H\&S performance of the organisation. Smallwood (2004) also found that Shell, a private client, has improved the H\&S performance of contracting organisations. The Pearson Chi-square analysis to see if there is an association between the two categories of clients and the impact of client involvement in $H \& S$ on the H\&S performance of organisations show no association at a significance level of $\leq .05$.

Table 9: consultants' perceptions of the impact of client involvement in H\&S on their organisations

\begin{tabular}{llll}
\hline Respondents & \multicolumn{3}{c}{ Responses } \\
\cline { 2 - 4 } & Yes & No & Total \\
& Freq. & Freq. & Freq. \\
\hline Public clients & 40 & 5 & 45 \\
Private clients & 13 & 9 & 22 \\
\hline Overall & 53 & 14 & 67 \\
\hline
\end{tabular}

Table 10 shows that overall, as a result of client involvement in H\&S, accidents have mostly been reduced, followed by an increase in productivity. This is in agreement with Smallwood (1998) who found that as a result of client involvement in H\&S, there were few accidents, increased productivity, inter alia, a reduction in rework. Analogously, in 2004, Smallwood reports that private clients' involvement in H\&S has improved contractor $H \& S$ in terms of increased productivity, increased client satisfaction to name but few. The Chi-square $(U)$ test at a significant level ( $p$-value $(p)$ ) of $\leq .05$ showed differences in the responses of the respondents in the following: reduction in accidents where $U=1.061, p=5.88$; reduction in accident or compensation claim where $U=.890$ and $p=.641$; reduction in rework where $U=.25, p=.882$; improvement in worker and employer relationship where $U=3.820 ; p=.148$; reduction in absenteeism where $\mathrm{U}=$ $2.434, p=$. 296. The implication of this is that in a larger sample, it is unlikely that there is no agreement on the nature of improvement due to client involvement; it is unlikely to be due to chance.

Table 10: Nature of improvement due to client involvement in H\&S

Yes No Unsure




\begin{tabular}{|c|c|c|c|c|c|c|c|c|c|}
\hline Nature of improvement & $\begin{array}{l}\text { Public } \\
\text { Client }\end{array}$ & $\begin{array}{l}\text { Private } \\
\text { Client }\end{array}$ & Total & $\begin{array}{l}\text { Public } \\
\text { Client }\end{array}$ & $\begin{array}{l}\text { Private } \\
\text { Client }\end{array}$ & Total & $\begin{array}{l}\text { Public } \\
\text { Client }\end{array}$ & $\begin{array}{l}\text { Private } \\
\text { Client }\end{array}$ & Total \\
\hline Reduction in accidents & 39 & 12 & 51 & 1 & 1 & 2 & 1 & 0 & 1 \\
\hline $\begin{array}{l}\text { Reduction in accident or } \\
\text { compensation claims }\end{array}$ & 33 & 10 & 43 & 5 & 1 & 6 & 3 & 2 & 5 \\
\hline Reduction in reworks & 25 & 5 & 30 & 8 & 5 & 13 & 8 & 3 & 11 \\
\hline $\begin{array}{l}\text { Improvement in worker } \\
\text { employer relationship }\end{array}$ & 32 & 7 & 39 & 4 & 4 & 8 & 5 & 2 & 7 \\
\hline Increase in productivity & 39 & 9 & 48 & 1 & 4 & 5 & 1 & 0 & 1 \\
\hline Improve client satisfaction & 38 & 9 & 47 & 1 & 3 & 4 & 2 & 1 & 3 \\
\hline Reduction in absenteeism & 22 & 8 & 30 & 15 & 4 & 19 & 4 & 1 & 5 \\
\hline
\end{tabular}

\section{Conclusions, Implications and Recommendations}

A study that comparatively investigated public and private clients' attitudes, commitment and impact on H\&S is presented in this paper. This stems from the gap in knowledge in client's attitudes and involvement in H\&S in the Nigeria construction industry and the underexamination of the discourse while factoring in the differences in clients. This is despite the differences in the needs, characteristics, and behaviours of clients who have the potential to improve H\&S.

The study shows that the attitudes and commitment of public clients are better than that of private clients. These differences can be explained by a lot such as the nature of projects that the clients engage in; their financial strengths; the type of contractors they engage, for example, large or small contractors; the type of construction, for example, formal or informal construction; and the procurement route. Typically, of the PPIs (cost, quality, productivity, $\mathrm{H} \& \mathrm{~S}), \mathrm{H} \& \mathrm{~S}$ was viewed as the least important overall and even between public and private clients, suggesting that $\mathrm{H} \& \mathrm{~S}$ awareness is poor. There is also evidence in the study that overall, clients are not committed to H\&S economically. This is where majority does not provide funds in excess of the budget cost for H\&S. However, more of public clients provide funds in excess of the budget cost than the private clients do. The major client H\&S practices tend to be mostly construction site appearancerelated namely: site visits, inspections and attending H\&S meetings. Other practices such as $\mathrm{H} \& \mathrm{~S}$ audit and engaging in $\mathrm{H} \& \mathrm{~S}$ awareness rank very low overall and in both public and private clients comparatively. The difference in the H\&S attitudes and involvement of the two categories of clients is underscored by the results of the inferential statistics. Indeed, the Mann-Whitney $U$ test showed a significant difference between the types of client and accident investigation and between the types of client and clients auditing of contractors H\&S records at preconstruction stage. Furthermore, Pearson Chi-square test shows that there is no statistical association between the two categories of clients and all but two client H\&S practices namely, clients insisting that contractors report accidents and that contractors obtain a permit to work.

The implications of these findings will be helpful to academics, policy makers, clients, and industry associations with interest in improving client involvement in $H \& S$ in Nigeria's construction industry. Typically, academics, policy makers and industry associations are now aware that public clients are more involved in H\&S than private 
clients especially in terms of site-appearance-related H\&S activities. Consequently, policy makers can develop policies that, among many, emphasise client involvement in $\mathrm{H} \& \mathrm{~S}$ at the preconstruction stage including ensuring that the hazards to workers are designed out. Also, as the literature review shows that the public clients have structural advantage over the private clients and the findings of the study show the possible implications of this, there is need for policymakers factor in these difference in policymaking. This means that the 'one policy fits all' approach in policymaking may not be as effective as when the differences between the public and private clients are considered. Based on the findings of the study, it is logical to conclude that academics overlooking the difference between the private and public clients and its implications may be viewed as fitting 'a round peg in a square hole'. Clients are also now aware of the impact of their involvement in H\&S, so they can make informed decisions. Furthermore, the practical implications of the findings of the study include the imperativeness of economic-based measures for improving clients' attitudes and involvement in $\mathrm{H} \& \mathrm{~S}$, especially as literature review shows the implications of lack of funds for H\&S improvement. The study also demonstrates the imperativeness of assigning more responsibilities to consultants in terms of influencing client attitudes towards H\&S. Scoping the study to the international readers, the current study reinforces the role of positive client attitude and commitment in $\mathrm{H} \& \mathrm{~S}$. This is because the study reflects a contrasting situation.

Drawing on the literature review, results and discussion and the implications above, the following are recommended. Efforts should focus on improving the level of H\&S awareness among clients, as a good understanding of the benefits of $H \& S$ will improve clients' attitudes and involvement in H\&S, especially at the preconstruction stage, a recommendation for policymakers, industry association, consultants. This can be complemented with strategies (including economic incentive-based regulatory measures) that factor in the differences in clients, a recommendation for policymakers; else, a particular category of the client will be overlooked. Measures such as this will encourage self-compliance and may result in more clients engaging in preconstruction $\mathrm{H} \& \mathrm{~S}$ practices as against the site appearance-based practices, which are common in the reported study. As it is unknown empirically why clients will be involved in H\&S or not, future research of qualitative strategies and methods can seek to address that. Also, academics can conduct further research to establish how to get client involvement in nonsite appearance based activities improved, perhaps an interpretivist paradigm study. Literature review reveals the need for a study to investigate the extent the characteristics and contexts of the public and private clients impact on them comparatively. Furthermore, although it is not the aim of this study to examine the extent of client involvement at various stages of projects, future research can address that.

\section{Reference}

- Ajayi, O. and Thwala, W.D. (2012). 'Dynamics Of Health And Safety In Nigeria's Construction Industry: Construction Worker's Dilemma', In Nani G., Nkum R.K., Awere E., Kissi, E and Bamfo-Agyei, E. (Eds) Procs. 1st Applied Research Conference in Africa. (ARCA) Conference, 29-31 August 2012, Elmina, Ghana, pp. 430-441 
- Aje, I. (2012) 'The impact of contractor's prequalification on construction project delivery in Nigeria', Engineering, Construction and Architectural Management, Vol. 19 No 2, pp. 159-172.

- Alinaitwe, H. M. (2008). 'An assessment of clients' performance in having an efficient building process in Uganda', Journal of Civil Engineering and Management, Vol.14 No 2, pp. 73-78.

- Business Roundtable (1991). Improving construction safety performance. Report A-3. The Business Roundtable, Washington.

- Cohen, J. (1988). 'Statistical power analysis for the behavioral sciences' (2nd ed.). Hillsdale, NJ: Lawrence Earlbaum Associates.

- Dantata, S. (2007). General Overview of the Nigeria Construction Industry. Unpublished MEng Dissertation, Massachusetts Institute of Technology, Cambridge, USA.

- Darling, S. D. and Cunningham, J., B. (2016), 'Underlying values and competencies of public and private sector managers', Asian Education and Development, Vol. 5 No 4, pp. 371-387.

- Diugwu I.A., Baba D. L., and Egila A. E. (2012). 'Effective regulation and Level of Awareness: An expose of the Nigeria's construction industry', Open Journal of Safety Science and Technology, (2),pp. 140-146.

- Emmons, J. (2007) 'Why contractor safety is important for owner: today's owners face a variety of risks when they undertake a construction project', Buildings, 101(4), pp.42(5)

- Fellows, R. and Liu, A. (1997), 'Research methods for construction', Blackwell Science, London.

- Gibb, A., Lingard, H. Behm, M and Cooke, T. (2014), 'Construction accident causality: Learning from different counties and different consequences', Construction Management and Economics, Vol. 32 No. 5, pp 446-459

- Hare, B. and Cameron, I. (2012), 'Health and safety gatways for construction project planning. Engineering, Construction and Architecture Management, Vol. 19 Iss 2, pp. 192-204.

- Hare, B.,Cameron, I. and Duff, 200 (2006), 'Exploring the integration of Health and safety with pre-construction planning. Engineering, Construction and Architecture Management Vol. 13 Iss 15, pp. 438-450.

- Health and safety executive (HSE) (2015), 'Managing health and safety in construction: Construction Design and Management', available at http://www.hse.gov.uk/pubns/priced/1153.pdf (accessed on 06-10-15).

- Health and Safety Executive (2014). Health and safety in construction in Great Britain, available at from http://www.hse.gov.uk/Statistics/industry/construction/construction.pdf (accessed on 8 $-10-15)$

- Hung, M. Y. (2006). 'Client's contributions to project safety performance: A comparison between public and private construction projects'. University of Hong Kong, University of Hong Kong, Hong Kong, available at http://hub.hku.hk/bitstream/10722/48905/1/b37943145.pdf (acessed on $18-10-15$ ) 
- Huang, X. and Hinze, J. (2006). 'Owner's role in construction safety'. Journal of Construction Engineering and Management, Vol. 132 No 2, pp. 164-173.

- Idoro, G. I. (2012), 'Evaluating Levels of Project Planning and their Effects on Performance in the Nigerian Construction Industry', Construction Economics and Building, Vol. 9 No. 2, pp. 39-50.

- International Labour Organisation (ILO) (2009), 'World day for safety and health at work 2009: Facts on safety and health at work', ILO, Geneva. Retrieved on 23-08-15 from

http://www.ilo.org/wcmsp5/groups/public/@dgreports/@dcomm/documents/publicati on/wcms_105146.pdf

- Kheni, N. A, Gibb A. G. F, Andrew, R. J. and Dainty, M (2010), 'Health and safety within Small- and medium-sized enterprises (SMEs) in developing countries: study of contextual influence', Journal of Construction Engineering and Management Vol. 135 No 10, pp. 1104-1115.

- Kikwasi, G. J. (2008), 'Client involvement in construction safety and health', In Hinze, J., Bohner, S., and Lew, J. (Ed.), Proc.: CIB W099 International Health and safety Conference: $14^{\text {th }}$ Rinker International Conference, 9- 22 March. Gainesville, Florida, USA, pp. 55-67.

- Kometa, S. T., Olomlaiye, P. O. and Harris, F. C. (1995), 'An evaluation of clients' needs and responsibilities in the construction process', Engineering, Construction and Architectural Management, Vol. 2 No 1, pp. 57-76.

- Kometa, S. T., Proverbs, D., and Olomlaiye, P. 0. (1997) 'An evaluation of the construction client's effort in achieving their project needs. COBRA 97, Royal Institution of Chartered Surveyor (RICS) Research, available at https://www.academia.edu/561222/AN_EVALUATION_OF_CONSTRUCTION_CLI ENTSEFFORT_IN_ACHIEVING_THEIR_PROJECT_NEEDS (accessed on 08-1015)

- Lingard, H. Blismas, N. Cooke, T. (2009) 'The model client' International Journal of Managing Projects in Business, Vol. 2 Iss 1, pp. 131-140.

- Lu, W., Chen, Xi Chen, Ho, D. C. W., AND Wang, H. (2016), 'Analysis of the construction waste management performance in Hong Kong: The public and private sector compared using bug data', Journal of Cleaner Production, 112,pp. 521-531.

- Manu, P., Ankrah, N., Proverbs, D., Subashini, S. and Callaghan, E. (2009), 'Subcontracting versus health and safety: An inverse relationship. In: Lingard, H.,Cooke, T. and Turner, M., eds. CIB W099 2009 Conference, RMIT, Australia, 2123 October 2009. Australia, pp. $617-627$, available at http://www.irbnet.de/daten/iconda/CIB20198.pdf (accessed on 20-03-16).

- Musonda I. and Pretorius, J. H. C. (2015), 'Effectiveness of economic incentives on client's participation in health and safety prgrammes', Journal of South African Institution of Civil Engineering, Vol. 57 No 2,pp. 2-7.

- Musonda I. and Smallwood J. (2008), 'Client commitment and attitude to construction health and safety in Botswana'. In Verster J. J. P. and Marx H.J (Eds): Proc.: $5^{\text {th }}$ Post graduate Construction Industry Development board (cidb) conference, March 16-18, Bloemfontein, pp.11-21

- New, S., Green, K., and Morton, B. (2002), 'An analysis of private versus public sector responses to the environmental challenges of the supply chain', Journal Public 
Procurement, Vol. 2 No 1,pp. 93-105.

- Odediran S.J, Adeyinka B.F., Opatunji O.A. and Morakinyo K.O (2012), 'Business Structure of Indigenous Firms in the Nigerian Construction Industry', International Journal of Business Research \& Management (IJBRM), Vol. 3, No 5,pp. 255-264.

- Ogunde, A. O., Owolabi, D. J., Kokoyi, P. O. and Oloke, O. C. (2013), 'Evaluation of the level of compliance with Construction Design Management (CDM 2007) Regulations by clients in Nigeria' Covenant Journal of Research in the Built Environment, Vol. 1 No 1, pp. 1-14.

- Olatunji, O. A., Aje, O. I., Odugboye, 'F. (2007), 'Evaluating Health And Safety Performance of Nigerian Construction Site', CIB World Congress 2007, pp. 11761190.

- Rameezden, R. and Jaysena, E. (2013), 'Comparing the procurement section parameters of private and public sector clients', International Journal of Construction Project Management, Vol. 5 No 2,pp. 171-184.

- Smallwood, J. (1998), 'Client influence on contractor health and safety in South Africa', Building Research and information, Vol. 26 No 3,pp. 181-189

- Smallwood, J. J. (2004), 'The influence of Clients on Contractors health and safety (H\&S)'. In Khosrowshahi, F (Ed), $20^{\text {th }}$ Annual Association of Researchers in Construction Management (ARCOM) conference, 1-3 September 2004, Heriot Watt University, Vol. 2,pp 1095-105.

- Sullivan, G. M. and Feinn, R (2012), 'Using effect size - or why the P value is not enough', Journal of Graduate Medical Education, pp.279-282.

- Summer, S. and Farrell, P. (2003), 'The influence of clients on health and safety standards in construction', In Greenwood, D. J. (Ed), $19^{\text {th }}$ Annual Association of Researchers in Construction Management (ARCOM) conference, 3-5 September 2003, University of Brighton, Vol.1, pp. 193-202.

- Tadelis, S. (2012), 'Public procurement design: Lessons from the private sector', International Journal of Industrial Organization, Vol. 30, pp. 297-302.

- Ulubeyli, S., Kazaz, A. and Er, B. (2014), 'Health and safety perception of workers in Turkey: A survey of construction sites' International Journal of Occupational Safety and Ergonomics, Vol. 20 No 2, pp. 323-338.

- Umeokafor, N. I (2015), 'An assessment of the influence of contextual environment on health and safety practices in the Nigerian construction industry', In Behm, M and McAleenan (Ed.), Proc.: CIB W099 International Health and safety Conference: Benefitting Workers and Society through inherently safe construction, 10-11 Sept. Northern Ireland, UK,pp. 397-406

- Umeokafor, N. I. (2016), 'Approaches, drivers and motivators to health and safety self-regulation in the Nigerian construction industry: a scoping study', Architectural Engineering and Design, Vol.12 No6, pp. 460-475.

- Umeokafor, N. I. (2017), 'Barriers to construction health and safety self-Regulation: A scoping case of Nigeria', The Civil Engineering Dimension (Dimensi Teknik Sipil), Vol. 19 No1, pp. 44-53.

- Umeokafor, N. I. and Windapo, A. O (2016), 'A framework for managing contextual influence on health and safety on construction projects'. In Windapo, A.O, Odediran, S. J. and Adediran, A.; Proc. $9^{\text {th }}$ Construction Industry Development Board (CIDB) postgraduate conference, 2-4 Feb. 2016, Cape Town, South Africa, pp. 285-294. 
- Valerie, F. Lingard, H., Prosser, A. and Turner, M. (2013), 'Work-family and Construction: Public and Private sector differences', Journal of Management in Engineering, Vol. 29 No 4,pp. 392-399. 